информационных и коммуникационных технологий в образовании / С. В. Панюкова. М. : Издательский центр «Академия», 2010. - 224 с. 8. Раицкая Л. К. Интернетресурсы в преподавании английского языка в высшей школе: классификация, критерии оценки, методика использования : [монография] / Л.К. Раицкая. - М. : МГИМОУниверситет, 2007. - 199 с. 9. Desk Videoconferencing: Novelty or Legitimate Teaching Tool? [Electronic Resource] // EducationWorld: [Site]. - Access mode: http://www.educationworld. com/a_curr/curr120.shtml

УДК $159.9: 371.134$

Світлана Карсканова

\title{
ВІД ПРОФЕСІЙНОГО САМОВИЗНАЧЕННЯ ДО ПРОФЕСІЙНОГО РОЗВИТКУ МАЙБУТНЬОГО ВЧИТЕЛЯ
}

Карсканова С. В. Від професійного самовизначення до професійного розвитку майбутнього вчителя.

У статті розглянуто професійне самовизначення молоді та подальший розвиток вчителя. Проаналізовано складники професійного зростання фахівця освіти. Обгрунтовано пріоритет активних методів навчання для розвитку фахівця освіти та психологічний тренінг як засіб забезпечення його професійного розвитку.

Ключові слова: професійне самовизначення молоді, професійні мотиви, професійний розвиток, психологічний тренінг.

Карсканова С. В. От профессионального самоопределения к профессиональному развитию будущего учителя.

В статье рассматривается профессиональное самоопределение молодежи и дальнейшее развитие учителя. Анализируются составляющие профессионального роста. Обосновывается приоритет активных методов обучения для развития специалиста образования и психологический тренинг как средство обеспечение его профессионального развития.

Ключевые слова: профессиональное самоопределение молодежи, профессиональные мотивы, профессиональное развитие, психологический тренинг.

Karskanova S. V. From professional self-determination to professional development of future teacher

The paper considers the self-determination of young professional and further development of the teacher. Analyzes the components of professional development and professional education. Substantiates the priority of active learning for the development of professional education and psychological training as providing.

Key words: professional development of young, professional motivation, psychological training.

Модернізація освіти в Україні зумовила багато питань, розв'язання яких неможливе без основних учасників цього процесу - фахівців освіти. Кожна країна зацікавлена в тому, щоб підготувати когорту таких учителів, які б не лише забезпечували кількісну реалізацію завдань обов'язкового навчання, але й підносили на значно вищий рівень освіченість і культуру іiі громадян. Здійснити професійну підготовку такого фахівця надзвичайно складно. На перешкоді стають об'єктивні і суб'єктивні чинники, породжені суспільними перетвореннями, технічними здобутками, стереотипами і формалізмом сучасної системи 
професійної підготовки, мотивованістю і ціннісними орієнтаціями майбутніх педагогів.

Нині зростає необхідність у спеціалістах, здатних ефективно розв'язання проблеми планування й реалізації власної кар'єри. У зв'язку 3 цим виникає необхідність формування в молодого покоління активного й творчого ставлення до проблем самоорганізації, самовизначення й самореалізації. Тому одним із пріоритетних завдань системи освіти України на сьогодні $\epsilon$ професійне самовизначення та подальший розвиток вчителя.

Mema cmammi. 3-поміж проблем професійного самовизначення молоді щодо різних спеціальностей особливої значущості набуває аспект вибору педагогічної професії, адже саме вчитель має розв'язувати такі глобальні питання, як засвоєння учнями базових знань 3 основ наук, формування світогляду й засвоєння молоддю системи суспільних цінностей.

Проблема професійного самовизначення особистості у фаховій літературі $\epsilon$ однією 3 широко досліджуваних. У працях різних дослідників цей термін часто ототожнюється 3 такими поняттями, як «професійне зростання» (Л. Божович, Є. Клімов, О. Міненко, Ю. Поваренков, М Поташнік, А. Самойлова, М. Пряжніков та ін.), «професійна самореалізація» (К. Роджерс, А. Маслоу, Д. Сьюпер та ін.), «професійна ідентифікація» (К. Абульханова-Славська, Л. Кален, Ю. Поваренков, та ін.), «професіоналізація» (І. Андрійчук, А. Маркова, Л. Мітіна, В. Панок, Н. Пов’якель, Л. Уманець, Н. Чепелєва та ін.), «кар'єра» (Є. Борисова, Дж. Дібс, А. Маслоу, Т. Парсонс) тощо. На нашу думку, усі ці поняття відображають процес професійного становлення фахівця протягом життя, але мають свою специфіку.

Дослідження проблеми професійного самовизначення виокремлюють два підходи. Представники першого підходу, якого дотримувались переважно радянські науковці (Л. Божович, М. Гінзбург, О. Мешковська тощо), вважають професійне самовизначення особистості одномоментним актом вибору професії, який завершується зі вступом індивіда до професійного навчального закладу або працевлаштуванням. На думку представників другого підходу (І. Андрійчук, Л. Долинська, Є. Клімов, В. Панок, М. Пряжніков, Н. Шевченко та ін.), професійне самовизначення $€$ тривалим процесом самореалізації професіонала в обраній спеціальності. Ми підтримуємо цей підхід і погоджуємось 3 думкою Є. Борисової про те, що професійне самовизначення $\epsilon$ складним особистісним утворенням, яке виявляється в «самореалізації особистості у професійній діяльності в результаті найбільш повного використання нею власних здібностей й індивідуальнопсихофізіологічних можливостей».

У роботах науковців представлена проблема оновлення змісту професійної підготовки майбутніх педагогів відповідно до європейських стандартів. Автори підкреслюють, що на сучасному етапі розбудови системи вищої педагогічної освіти України відбувається не проста заміна лекційно-семінарської системи викладання на європейську, а поєднання кращих здобутків традиційного й особистісно зорієнтованого навчання.

Психолого-педагогічними умовами, що сприяють формуванню у майбутніх фахівців педагогічних спеціальностей високого рівня професійного самовизначення, такі:

- навчання, яке грунтується на принципах гуманістично-орієнтованої освіти;

- поєднання позитивних надбань лекційно-семінарської системи й особистісно зорієнтованого навчання;

- пріоритет вищої педагогічної освіти особистісно-професійного розвитку 
майбутніх фахівців, підвищення уваги викладачів і психологів ВНЗ до проблем професійної спрямованості й самореалізації студентів;

- забезпечення необхідних умов для роботи студентів із власної професійної самоосвіти й самовиховання.

Професійні мотиви в майбутніх фахівців різних напрямків професійної підготовки формуються нерівномірно. Це пов'язано 3 тим, що професійна спрямованість особистості на обраний фах формується 3 допомогою наявності професійної мотивації та відповідно до неї професійних інтересів.

До типів мотивації вибору професії віднесемо:

- I тип мотивації - опорний тип - інтерес до професії гармонійно поєднується 3 морально зрілою установкою на працю, 3 об'єктивною оцінкою і практичною перевіркою особистих якостей, готовністю до самовиховання;

- II тип мотивації - молодь заздалегідь неясно представляє специфіку обраної професії, обмеження іiі вибору, зумовлені вимогами до стану здоров'я, фізичних, розумових та інших якостей людини;

- III тип мотивації характеризується неузгодженістю між інтересом до професії та мотивами суспільного обов'язку;

- IV тип мотивації найменш ефективний: у виборі професії молоді люди керуються лише своїми бажаннями, без адекватного усвідомлення як суб'єктивних, так і об'єктивних можливостей та умов їх реалізації.

Професійне зростання педагога, на думку М. Поташніка,- це мета і процес надбання знань, умінь, способів діяльності, що дозволяють йому не будь-як, а оптимально реалізувати своє призначення. Отже, оптимально професійного зростання означає отримання максимально можливих для конкретних умов результатів цього росту за мінімально необхідних витрат часу, сил, засобів тощо. Професійне зростання педагога здійснюється двома шляхами: за допомогою самоосвіти та через усвідомлене, обов'язково добровільне навчання [3]. Ці шляхи нерозривно пов'язані: педагог сам обирає зміст, форми, методи з пропонованої йому роботи, і тому остання набуває характер самоосвіти, з іншого боку, як би педагог сам не піклувався про свій професійний ріст, як би ретельно сам не проектував його, він не може як шовкопряд нескінченно витягати тільки із самого себе «нитку» знань, умінь, ідей.

Пізнавальна активність фахівця знаходить вияв у ставленні особистості до пізнавальної діяльності, самостійному пізнанні та діагностується підвищенням психолого-педагогічних, предметних, методичних знань i розширенням загальнокультурного світогляду. Операційно-технологічна активність педагога визначає вдосконалення наявних умінь і навичок, формування нових та використання у професійній діяльності нових стратегій відреагування. Уявлення різних образів і картин, тобто візуалізація уміння комбінувати різні уявлювані образи, дає змогу виявити їх оптимальне поєднання у творчому процесі. 3 набуттям уміння керувати власним інтуїтивним баченням, внутрішніми образами відбувається просування від невизначених абстрактних бажань до конкретного планування. Саме цей перехід від абстрактної ідеї до конкретних моделей поведінки становить сутність психотренінгу самонавіювання. Таку активну настанову, людина дає собі у словесній формі. Система керування станом свідомості передбачає прийоми розвитку уяви, волі, пам'яті.

Тенденції взаємовпливу психічних процесів, якостей та станів особистості, які були виявлені нами, дозволили обрати найефективнішу форму здійснення особистісної підготовки фахового зростання та корекції неблагополуччя професіонала - психологічний тренінг. Методологічною (технологічною) основою 
тренінгу став проблемний (емоційно-регулювальний) підхід, уплетений у практику реального спілкування (частково - у професійній, частково - у цілісній життєвій площині) [2]. Інформаційно-регулятивною базою стали норми та цінності - 3 одного боку, реалії професійної діяльності - з іншого.

Під впливом тренінгу, подальшого консультування у фахівця відбуваються суттєві структурні зміни в мотивації набуття знань та досягнення в напрямку зростання питомої ваги внутрішньої мотивації, зрушення в системі особистісних рис, відбувається посилення тенденції до самодетермінації і свідомого керування особистістю власною мотивацією. Вправи тренінгу спрямовують на розвиток мотивації досягнення та інтересу до діяльності, якою фахівці опікуються. Виконання подібних вправ $\epsilon$ особливо актуальним, коли суб'єкт втратив інтерес до своєї професійної діяльності, перебуває на стадії стагнації (згідно з позицією Л. Мітіної), чи коли цей інтерес суттєво знизився. Виконання таких вправ розвиває здатність до самомотивації (людина набуває здатності та вміння надихати та спонукати самого себе до дій). Це стосуюється впливу самоефективності (О. Бандура), впливу на вибір кар'єрного спрямування, на іiі подальший розвиток. Чим впевненіша людина у своїх можливостях, тим більше варіантів кар'єри вона розглядає, тим вищий інтерес, який вона виявляє до цих можливостей, тим краще вона готує себе для виконання різних професійних справ і тим вона успішніше в них [4].

Цілеспрямована робота 3 оптимізації професійного самовизначення майбутніх учителів має поєднувати як методи традиційної системи викладання у модифікованому варіанті (міні-лекції), так і тренінгові технології, а саме - активне соціально-психологічне навчання та такі конкретні засоби цього методу, як рольові й ділові ігри, ігри з елементами психодрами, метод психомалюнку, індивідуальні й групові консультації, диференційовані домашні завдання, складання студентами планів власного професійного саморозвитку тощо [1].

Кожного професіонала завжди цікавили способи, прийоми, які допомогли б йому активізувати власне мислення, розвивати творчі здібності, формувати вміння розв'язувати нові життєво-важливі проблеми. Звернути увагу на те, що певні чинники сприяють більш продуктивній розумовій діяльності, що результати розумової праці бувають наслідком не тільки цілеспрямованого свідомого пошуку, а й щасливою здогадкою, допомагають методи ТРВ3 (теорія рішення винахідницьких завдань). Менш популярні, але давно практикуються й інші методи: морфологічний аналіз, алгоритм розв'язання винахідницьких завдань (Арізо), «гірлянди асоціацій», стратегія семикратного пошуку, конференція ідей, колективні записні книжки. Деякі з цих методів вважаються досить універсальними, придатними для розв'язання творчих завдань у різних сферах трудової діяльності. Таким методам простіше всього навчитися на тренінгах.

Як показують дослідження А. Бандури, не достатньо мати тільки певні психологічні характеристики, які зумовлюють успішність виконання тієї чи тієї діяльності, потрібна ще і тверда впевненість людини у здатності реалізувати їх у відповідній ситуації [4].

Наші дослідження показали, що специфіка креативного стану педагогів поєднання творчого піднесення, автономності, сформованості внутрішньої моделі ідеалу результату, совісність, емоційна стабільність та використання сукупності сприятливих супутніх творчості умов, що разом породжують новий спосіб практичної професійної діяльності. Ключовими бар'єрами креативного стану педагогів, який сприяє професійному розвитку, є екстравертивна орієнтація, чутливість до оцінок і 
ставлення навколишніх, тенденція до невротичності та виснаження психічної енергії в ході інтенсивного емоційного контактування, участь педагогів.

Феномен професійного самовизначення має розглядатися комплексно 3 професійним розвитком, як цілеспрямована активність індивіда 3 якомога більш повної реалізації своїх здібностей, можливостей у конкретному виді професійної діяльності. Базовим компонентом такої активності є усвідомлення ним вимог обраної професії, міри власної придатності до неї та перспектив власного професійного зростання.

\section{Література}

1. Гріньова О. М. Професійне самовизначення майбутніх педагогів як фактор успішності їх професійної діяльності / О. М. Гріньова // Проблеми загальної та вікової психології: збірник наукових праць Інституту психології ім. Г. С. Костюка АПН України / за ред. Максименка С. Д. - К. : Логос, 2008. - Т. Х. - Ч.2. - С. 168-179. 2. Карнизова Л. М. Самоопределение профессионала в проблемной ситуации / Л. М. Карнизова // Вопросы психологии. - 1990. - № 6. - C.75-82. 3. Поташник М. М. Управление профессиональным ростом учителя в современной школе : [метод. пособие] / M. М. Поташник. - M. : Центр педагогического образования, 2009. - 448 с. 4. Bandura A. Social foundation of thought and action : A social cognitive theory. - N.Y., 1986. - Englewood Cliffs, Prentice-Hall.ISBN 9780138156145. ISBN 013815614X, OCLC $12080269-617$ p.

Олександр Коваленко

\section{СУЧАСНИЙ СТАН ПРОБЛЕМИ ФОРМУВАННЯ ПРОФЕСІОНАЛІЗМУ МАЙБУТНІХ ЕКОНОМІСТІВ}

Коваленко О. В. Сучасний стан проблеми формування професіоналізму майбутніх економістів.

У статті проаналізовано сучасний стан проблеми формування професіоналізму майбутніх економістів, розглянуто чинники, що визначають рівень підготовленості економіста до професійної діяльності, виокремлено рівні професійної спрямованості студентів, а також визначено критерії сформованості професійних знань студентів економічних спеціальностей.

Ключові слова: структура діяльності економіста, професійно значущі якості фахівця, професійна спрямованість студентів.

Коваленко О. В. Современное состояние проблемы формирования профессионализма будущих экономистов.

В статье проанализировано современное состояние проблемы формирования профессионализма будущих экономистов, рассмотрены факторы, определяющие уровень подготовленности экономиста к профессиональной деятельности, выделены уровни профессиональной направленности студентов, а также определены критерии сформированности профессиональных знаний студентов экономических специальностей.

Ключевые слова: структура деятельности экономиста, профессионально значимые качества специалиста, профессиональная направленность студентов.

Kovalenko O. V. Modern state of problem of forming of professionalism of future 